\title{
Effects of growth reducer and nitrogen fertilization on morphological variables, SPAD index, interception of radiation and productivity of wheat
}

\author{
Elvis Felipe Elli ${ }^{1 *}$, Braulio Otomar Caron ${ }^{2}$, Sandro Luis Petter Medeiros ${ }^{3}$, Elder Eloy, \\ Gean Charles Monteiro ${ }^{1}$, Denise Schmidt ${ }^{2}$ \\ http://dx.doi.org/10.1590/0034-737X201562060010
}

\begin{abstract}
The objective of this study was to evaluate the effect of growth reducer and nitrogen fertilization on morphological variables, SPAD index, radiation interception, and grain yield of three cultivars of wheat. The experimental design was a randomized block in factorial scheme $3 \times 5 \times 2$, with three cultivars (Mestre, Iguaçú and Itaipú), five nitrogen doses $\left(0,40,80,120,160 \mathrm{Kg} \mathrm{ha}^{-1}\right)$, and application or no application of a growth reducer, with three replications. The following characteristics were evaluated: plant height, SPAD index, leaf area index (LAI), Global Radiation Interception (GRI) and grain yield. The Tukey test $(\mathrm{p}<0.05)$ was used for the comparison between the means of cultivar and growth reducer factors, and for a regression analysis to evaluate $\mathrm{N}$ levels. Increasing the dose of nitrogen promotes an increase in LAI of plants of wheat crops differently among cultivars, which leads to a greater degree of global radiation interception. At doses higher or equal to $120 \mathrm{Kg} \mathrm{ha}^{-1}$ of nitrogen, there are significant differences in grain yield between treatments with and without the application of the growth reducer. The significant interaction between growth reducer and nitrogen dose, showed that applications of growth reducer increase the GRI at doses above and below $80 \mathrm{Kg} \mathrm{ha}^{-1}$ of nitrogen. Nitrogen rates of 138 and $109 \mathrm{Kg} \mathrm{ha}^{-1}$ are responsible for maximum grain yields of wheat, which is 4235 and $3787 \mathrm{Kg} \mathrm{ha}^{-1}$ with and without the use of growth reducer, respectively.
\end{abstract}

Key words: Triticum aestivum, trinexapac-ethyl, photosynthetic rate.

\section{RESUMO}

\section{Efeitos de redutor de crescimento e adubação nitrogenada sobre variáveis morfológicas, índice SPAD, interceptação de radiação e produtividade de trigo}

O objetivo deste trabalho foi avaliar o efeito de redutor de crescimento e de adubação nitrogenada sobre variáveis morfológicas, índice SPAD, interceptação de radiação global e produtividade, de três cultivares de trigo. O delineamento experimental utilizado foi o de blocos casualizados, em esquema fatorial $3 \times 5 \times 2$, com três cultivares (Mestre, Iguaçú e Itaipú), cinco doses de nitrogênio $\left(0,40,80,120,160 \mathrm{Kg} \mathrm{ha}^{-1}\right)$ e aplicação, ou não, de redutor de crescimento, com três repetições. Avaliaram-se altura de planta, índice SPAD, índice de área foliar (IAF), interceptação de radiação global (IRG) e produtividade de grãos. Utilizou-se o teste de Tukey ( $<<0,05$ ), para a comparação entre as médias dos fatores cultivar e redutor de crescimento, e análise de regressão, para avaliação das doses de $\mathrm{N}$. O aumento da dose de nitrogênio promove aumento no IAF de plantas na cultura o trigo, de forma diferenciada entre os cultivares, acarretando maior interceptação de radiação global. Em doses de nitrogênio maior ou igual a $120 \mathrm{Kg} \mathrm{ha}^{-1}$, há diferença significativa na produtividade do trigo entre os tratamentos com e sem a aplica-

\footnotetext{
${ }^{1}$ Universidade Federal de Santa Maria, Departamento de Ciências Agronômicas e Ambientais, Centro de Educação Superior Norte do Rio Grande do Sul, Frederico Westphalen, Rio Grande do Sul, Brasil. elvisfelipeelli@yahoo.com; gean.monteiro@yahoo.com.br

${ }^{2}$ Universidade Federal de Santa Maria, Departamento de Ciências Agronômicas e Ambientais, Centro de Educação Superior Norte do Rio Grande do Sul, Frederico Westphalen, Rio Grande do Sul, Brasil. otomarcaron@yahoo.com.br; denise@ufsm.br

${ }_{3}^{3}$ Universidade Federal de Santa Maria, Departamento de Fitotecnia, Santa Maria, Rio Grande do Sul, Brasil. slpmedeiros@yahoo.com.br

${ }^{4}$ Universidade Federal do Paraná, Departamento de Engenharia florestal, Curitiba, Paraná, Brasil. eloyelder@yahoo.com.br

*Corresponding author: elvisfelipeelli@yahoo.com
} 
ção do redutor de crescimento. A interação significativa entre redutor de crescimento e dose de nitrogênio mostrou que a aplicação de redutor aumenta o IRG nas doses acima e abaixo de $80 \mathrm{Kg} \mathrm{ha}^{-1}$ de nitrogênio. As doses de nitrogênio de 138 e $109 \mathrm{Kg} \mathrm{ha}^{-1}$ são responsáveis pela produtividade máxima da cultura do trigo, sendo de 4235 a $3787 \mathrm{Kg} \mathrm{ha}^{-1}$, com e sem a utilização do redutor de crescimento, respectivamente.

Palavras-chave: Triticum aestivum, trinexapac-ethyl, taxa fotossintética.

\section{INTRODUCTION}

The response of wheat (Triticum aestivum L.) to nitrogen fertilization in grain productivity depends on the amount of nitrogen $(\mathrm{N})$ applied, since the use of high amounts of $\mathrm{N}$ can lead to increased vegetative growth, which causes lodging of the plants and affects yield and grain quality (Buzetti et al., 2006).

Among the strategies for use of high doses of nitrogen in wheat, there is the application of growth reducers. Among them, trinexapac-ethyl has long been used, which affects the end of the metabolic pathway of the gibberellic acid biosynthesis by inhibiting the enzyme 3-hydroxylase, drastically reducing the level of active gibberellic acid $\left(\mathrm{GA}_{1}\right)$, which acts on the internode elongation (Rademacher, 2000). From the assumption, observed by Lozano \& Leaden (2002), that trinexapacethyl, besides reducing plant growth, is able to modify the leaf architecture, mainly of wheat flag leaf, we emphasize the importance of verifying if it influences the overall amount of global radiation intercepted by the plant and, hence, the photosynthetic rate and productivity of wheat grain.

Knowledge of the influence of these factors (nitrogen doses and growth reducer) on the global radiation interception (GRI), as well as on other variables that also modify the amount of radiation intercepted by the crop, such as leaf area index (LAI), SPAD index and plant height, can bring relevant information to increase productivity of wheat, by reason of greater use of global incident radiation on the plant canopy.

The aim was to evaluate the effect of growth reducer and nitrogen fertilization on morphological variables, SPAD index, global radiation interception and productivity of three wheat cultivars.

\section{MATERIAL AND METHODS}

The study was conducted in the experimental area of Laboratório Agroclimatologia, linked to the Universidade Federal de Santa Maria, campus Frederico Westphalen, RS, with geographic location $27^{\circ} 23^{\prime} 48^{\prime \prime} \mathrm{S}$, $53^{\circ} 25^{\prime} 45^{\prime \prime} \mathrm{W}$ and altitude of $490 \mathrm{~m}$. According to the Köppen climate classification, the prevailing climate is
$\mathrm{Cfa}$, characterized as humid subtropical, with an average annual temperature of $18.8^{\circ} \mathrm{C}$ and average temperature of the coldest month of $13.3^{\circ} \mathrm{C}$ (Maluf, 2000).

The soil of the area belongs to the unity of Passo Fundo, classified as typical Oxisol, clayey texture, deep and well drained (Embrapa, 2006), with the following chemical characteristics: $\mathrm{pH}$ in water: 6.0 ; $\mathrm{P}$ (Mehlich): $3.0 \mathrm{mg} \mathrm{dm}$ 3; K: $160 \mathrm{mg} \mathrm{dm}^{-3}$; Ca: $6.2 \mathrm{cmol}_{\mathrm{c}} \mathrm{dm}^{-3} ; \mathrm{Mg}: 3.3 \mathrm{cmol}_{\mathrm{c}} \mathrm{dm}^{-}$ ${ }^{3}$; Al: $0.0 \mathrm{cmol}_{\mathrm{c}} \mathrm{dm}^{-3}$; CTC: $9.9 \mathrm{cmol}_{\mathrm{c}} \mathrm{dm}^{-3}$; base saturation: $76 \%$ and organic matter $3.1 \%$. Fertilization was performed, at sowing, with phosphorus $\left(\mathrm{P}_{2} \mathrm{O}_{5}\right)$, in the amount of $70 \mathrm{~kg} \mathrm{ha}^{-1}$. There was no need for potassium application, on account of the very high level existing in the soil, according to the results of soil analysis, following the technical indications of SBCS (2004).

The experimental design used was randomized blocks, in $3 \times 5 \times 2$ factorial design, with three cultivars (Mestre, Iguaçú and Itaipú), five doses of nitrogen (0, 40, 80, 120, $160 \mathrm{~kg} \mathrm{ha}^{-1}$ ) and application, or no application, of growth reducer, with three replications. The wheat cultivars (both average-height plants) were manually sown on June 6 , 2012, with density of 3.500 .000 seed ha $^{-1}$. The size of the plots was six rows of three meters in length, spaced $17 \mathrm{~cm}$, considering as border an outside line from each end of the plot. The nitrogen fertilizer was applied at the rate of $20 \mathrm{~kg} \mathrm{ha}^{-1}$ at sowing and the rest, at top dressing, in the early tillering stage.

We used a slow-release $\mathrm{N}$ fertilizer (SRNF), with $26 \% \mathrm{~N}$. The identification of phenological stages was performed according to the scale proposed by Feeks \& Large (Large, 1954). Trinexapac-ethyl was applied at a dose of $100 \mathrm{~g} \mathrm{ha}^{-1}$ by knapsack sprayer, with an average application speed of $5.5 \mathrm{~km} \mathrm{~h}^{-1}$, in proportional spray volume of $130 \mathrm{~L} \mathrm{ha}^{-1}$. The applications were done when the plants were in flower differentiation, with the first visible node in stage 6.0.

The SPAD index was determined, using SPAD-502, which evaluated the last full leaf of each plant studied. In each evaluation leaf, we selected three points: basal, median and axial areas, with the determinations performed in the morning.

The global incident radiation $\left(\mathrm{w} \mathrm{m}^{-2}\right)$ was monitored with a pyranometer (LICOR PY32164) coupled to a 
Datalogger (LICOR 1400) in the period from 10 a.m. to 12 p.m. The global radiation interception values were obtained according to the equation proposed by Caron et al, (2012): \% Interception $=\left[100-\left(\mathrm{R}_{\mathrm{n}} \times 100 / \mathrm{R}_{\mathrm{t}}\right)\right]$, wherein $\mathrm{R}_{\mathrm{n}}=$ global incident radiation on the inside of the canopy; $\mathrm{R}_{\mathrm{t}}=$ global incident radiation on the top of the canopy. The plant leaf area was determined using a sample of $0.10 \mathrm{~m}^{2}$ per plot with a leaf area integrator LI 3100, LI-COR, NE, USA. Having the leaf area, the Leaf Area Index (LAI) was obtained, through the following equation: $\mathrm{LAI}=\mathrm{La} / \mathrm{As}$, where: $\mathrm{La}=$ leaf area; $\mathrm{As}=$ area of soil.

The plant height was measured with a graduated scale by selecting ten plants in the center of each plot. The variables SPAD index, GRI, LAI and plant height were determined the full flowering of the cultivars, at stage 10.5.4. Plants were harvested after the grains reached maturity (stage 11.4), and grain productivity was determined by collecting the plants contained in the four central rows of each plot. After manual tillering, the grains were weighed and the data transformed into $\mathrm{kg} \mathrm{ha}$ ${ }^{1}$, at $13 \%$ humidity.

Data were statistically analyzed by means of the computer program Statistical Analysis System Learning Edition 8.0 (SAS, 2003). We used the Tukey test (p < 0.05 ) for the comparison between the averages of the factors cultivar and growth reducer, and regression analysis to evaluate doses of $\mathrm{N}$.

\section{RESULTS AND DISCUSSION}

There was an effect of the interaction cultivar $\mathrm{x}$ dose on the SPAD index, LAI and the GRI, of cultivar $\mathrm{x}$ reducer on the height and of dose $\mathrm{x}$ reducer on the LAI, GRI and productivity. Regarding the Tukey test (Table 1), it can be seen that the cultivars showed difference in the SPAD and the LAI from the doses of 40 and $80 \mathrm{~kg} \mathrm{ha}^{-1}$, respectively, and the cultivar Mestre showed higher values of SPAD index in most doses compared with Itaipú and Iguaçú. As for the LAI, the Itaipú presented the highest values.

However, for the GRI, despite its increasing values with increasing nitrogen doses, significant differences were found in lower doses of nitrogen $\left(0\right.$ and $\left.40 \mathrm{~kg} \mathrm{ha}^{-1}\right)$, and the cultivar Itaipú had the highest values in both doses. This result shows that from a certain level of leaf expansion, radiation interception remains stable, even increasing the leaf area index, which may explain the production stability of many crops, even with increased doses of nitrogen.

This result can be supplemented by Alambert (2010) who argues that when there is increase in the LAI, global radiation interception increases, but only up to a certain value, which reaches the complete closure of the canopy. The leaves begin to shadow one another, until the critical LAI, when new leaf areas do not result in increased amount of intercepted light. These results agree with those reported by Elli et al. (2013), analyzing global radiation interception in soybean, due to different spatial arrangements and phenological stages. The different behavior of the LAI among cultivars corroborates the results presented by Loomis and Williams (1963), who established that the optimal LAI may vary by species, cultivar and season.

The productivity was influenced by the reducer, resulting in means higher than those obtained without application of the product (Table 1), behavior observed from the doses of $120 \mathrm{~kg} \mathrm{ha}^{-1}$. GRI also increased when applying the product, except at a dose of $80 \mathrm{~kg} \mathrm{ha}^{-1}$.

As for the interaction cultivar $\mathrm{x}$ reducer (Table 1), the application of the growth reducer promoted reduction in plant height. Regarding the LAI, the cultivar Mestre showed higher values with the application of this product, but the other cultivars had no significant effect on this variable. This behavior can be attributed to genetic effect. In this context, Pagliosa et al. (2013) indicate differences in the genetic potential between wheat BRS 208 and BRS Guamirim, wherein the first cultivar was influenced by the dose of trinexapac-ethyl, behavior not observed in the latter cultivar for the character grain number per ear.

This information is in line with that reported by Zagonel \& Fernandes (2007), in stating that even wheat cultivars of medium or small size, which are less responsive to trinexapac-ethyl, may have higher grain productivity, because the modification of its leaf architecture, aimed at capture more radiation. Furthermore, there is also a greater allocation of photoassimilates to produce grains, since there is a reduction in stem growth (Zagonel \& Fernandes, 2007).

There was no occurrence of lodging during the experiment, which can be justified, either by the use of SRNF or the use of medium-sized cultivars. Pagliosa et al. (2013), working with wheat cultivars BRS 208, BRS 220 and BRS Guamirim, using nitrogen fertilizer in the form of urea, did not identify the occurrence of lodging.

In the quantitative analysis (Figure 1), it can be seen that the SPAD index was influenced by increased $\mathrm{N}$ doses, responding positively to increased levels of this element, where the highest values were found for the dose of $118.75 \mathrm{~kg} \mathrm{ha}^{-1}$ (50.2) for the cultivar Mestre; $110.00 \mathrm{~kg} \mathrm{ha}^{-1}$ for Iguaçú (46.4) and $116.67 \mathrm{~kg} \mathrm{ha}^{-1}$ (44.1) for Itaipú. Viana \& Kihel (2010), working with different levels of $\mathrm{N}$ and potassium, in wheat, found similar results.

Regarding the LAI, there were quadratic behaviors of the three cultivars studied, compared to the increase 
in doses of $\mathrm{N}$. The highest LAI values were found at the rate of $150.71 \mathrm{~kg} \mathrm{ha}^{-1}$ (3.2) for cultivar Mestre ; 145.83 $\mathrm{kg} \mathrm{ha}^{-1}$ (3.4) for Iguaçú and $155 \mathrm{~kg} \mathrm{ha}^{-1}$ (4.0) for Itaipú.

This same characteristic of the curve was observed for the GRI in all cultivars, with increasing doses of $\mathrm{N}$, having the following maximum points: $113.31 \mathrm{~kg} \mathrm{ha}^{-1}(78.0 \%)$ for Mestre; $123.12 \mathrm{~kg} \mathrm{ha}^{-1}$ (76.6\%), for Iguaçú and 114.94 $\mathrm{kg} \mathrm{ha}^{-1}(76.5 \%)$ for Itaipú. According to these results, the high ratio between the LAI and the GRI is evidenced, corroborating the results of Pengelly et al. (1999), who found that the interception of solar radiation is a function of the LAI and light extinction coefficient (k).

When analyzing the influence of reducing growth factors and $\mathrm{N}$ doses on LAI (Figure 2), both graphic curves (using or not growth reducer) allowed the setting of a quadratic equation. GRI increased with increasing doses of nitrogen, also observed for the LAI and productivity.

The highest GRI was observed at the dose of 128.33 $\mathrm{kg} \mathrm{ha}^{-1}(80.6 \%)$, in the presence of growth reducer, and $106.09 \mathrm{~kg} \mathrm{ha}^{-1}(76.3 \%)$, without the use of reducer. The maximum points of LAI were observed at the dose of
153.8 (3.8) and $156.5 \mathrm{~kg} \mathrm{ha}^{-1}$ (3.1), while the productivity showed the highest values with the use of 137,70 (4234, $9 \mathrm{~kg} \mathrm{ha}^{-1}$ ) and $108.56 \mathrm{~kg} \mathrm{ha}^{-1}\left(3787.4 \mathrm{~kg} \mathrm{ha}^{-1}\right)$, for the treatments with and without the use of growth reducer, respectively (Figure 2). This result can be explained by the increased photosynthetic rate of the culture, caused by the presence of a greater leaf area available, more global radiation absorption and, consequently, of photosynthetically active radiation (PAR).

The fact that the LAI curve, in the treatment with growth reducer, presents the highest values, can be explained by the changing of leaf architecture, especially the flag leaf, by the action of the product. Similar results were found by Lozano \& Leaden (2002), evaluating the trinexapacethyl on two wheat cultivars, and the application of this product changed the angle of flag leaf, making it more upright in both cultivars studied. This behavior can provide better distribution of leaves in the canopy, thus increasing the interception of solar radiation, with less intraspecific competition, which may result in increased productivity (Zagonel \& Fernandes, 2007).

Table 1: Developments of interactions between wheat cultivars, growth reducer and nitrogen doses for SPAD index, leaf area index (LAI), global radiation interception (GRI), grain productivity and plant height

\begin{tabular}{|c|c|c|c|c|c|c|}
\hline \multicolumn{7}{|c|}{ Interaction Cultivar x Dose } \\
\hline \multirow{2}{*}{ Variable } & \multirow{2}{*}{ Cultivar } & \multicolumn{5}{|c|}{ Nitrogen Dose $\left(\mathrm{Kg} \mathrm{ha}^{-1}\right)$} \\
\hline & & $\mathbf{0}$ & 40 & 80 & 120 & 160 \\
\hline \multirow[t]{3}{*}{ SPAD Index } & Mestre & $37.93 \mathrm{a}$ & $47.63 \mathrm{a}$ & $47.35 \mathrm{a}$ & $50.05 \mathrm{a}$ & $49.51 \mathrm{a}$ \\
\hline & Itaipú & $39.66 \mathrm{a}$ & $42.83 \mathrm{c}$ & $43.53 \mathrm{~b}$ & $44.28 \mathrm{~b}$ & $44.36 \mathrm{c}$ \\
\hline & Iguaçú & $39.46 \mathrm{a}$ & $45.20 \mathrm{~b}$ & $46.40 \mathrm{a}$ & $44.85 \mathrm{~b}$ & $46.90 \mathrm{~b}$ \\
\hline \multirow[t]{3}{*}{ LAI } & Mestre & $1.92 \mathrm{a}$ & $3.24 \mathrm{a}$ & $2.30 \mathrm{~b}$ & $3.20 \mathrm{~b}$ & $3.31 \mathrm{~b}$ \\
\hline & Itaipú & $1.95 \mathrm{a}$ & $2.83 \mathrm{a}$ & $3.45 \mathrm{a}$ & $4.03 \mathrm{a}$ & $4.44 \mathrm{a}$ \\
\hline & Iguaçú & $1.97 \mathrm{a}$ & $2.72 \mathrm{a}$ & $3.00 \mathrm{ab}$ & $3.74 \mathrm{ab}$ & $3.16 \mathrm{~b}$ \\
\hline \multirow[t]{3}{*}{ GRI $(\%)$} & Mestre & $30.40 \mathrm{c}$ & $63.93 \mathrm{~b}$ & $72.75 \mathrm{a}$ & $74.67 \mathrm{a}$ & $72.09 \mathrm{a}$ \\
\hline & Itaipú & $52.14 \mathrm{a}$ & $70.09 \mathrm{a}$ & $72.69 \mathrm{a}$ & $75.75 \mathrm{a}$ & $73.93 \mathrm{a}$ \\
\hline & Iguaçú & $43.69 \mathrm{~b}$ & $68.95 \mathrm{ab}$ & $71.97 \mathrm{a}$ & $72.80 \mathrm{a}$ & $76.86 \mathrm{a}$ \\
\hline \multicolumn{7}{|c|}{ Interaction Reducer x Dose } \\
\hline \multirow{2}{*}{ Variable } & \multirow{2}{*}{ Reducer } & \multicolumn{5}{|c|}{ Nitrogen Dose $\left(\mathrm{Kg} \mathrm{ha}^{-1}\right)$} \\
\hline & & $\mathbf{0}$ & 40 & 80 & 120 & 160 \\
\hline \multirow{2}{*}{$\begin{array}{l}\text { Productivity } \\
\left(\mathrm{Kg} \mathrm{ha}^{-1}\right)\end{array}$} & With & $2276.99 \mathrm{a}$ & $3589.88 \mathrm{a}$ & $3634.58 \mathrm{a}$ & $4278.12 \mathrm{a}$ & $4193.02 \mathrm{a}$ \\
\hline & Without & $2505.32 \mathrm{a}$ & $3554.21 \mathrm{a}$ & $3574.92 \mathrm{a}$ & $3531.10 \mathrm{~b}$ & $3576.72 b$ \\
\hline \multirow[t]{2}{*}{ GRI $(\%)$} & With & $53.42 \mathrm{a}$ & $74.40 \mathrm{a}$ & $75.62 \mathrm{a}$ & $77.22 \mathrm{a}$ & $81.33 \mathrm{a}$ \\
\hline & Without & $45.84 \mathrm{~b}$ & $69.90 \mathrm{~b}$ & $73.82 \mathrm{a}$ & $73.04 \mathrm{~b}$ & $71.18 \mathrm{~b}$ \\
\hline \multicolumn{7}{|c|}{ Interaction Cultivar x Reducer } \\
\hline \multirow{2}{*}{ Variable } & \multirow{2}{*}{\multicolumn{2}{|c|}{ Reducer }} & \multicolumn{4}{|c|}{ Cultivar } \\
\hline & & & Mestre & & & Iguaçú \\
\hline \multirow[t]{2}{*}{ Height (cm) } & & With & $67.50 \mathrm{~b} \mathrm{~A}$ & 61. & & $66.12 \mathrm{~b} \mathrm{~A}$ \\
\hline & & Without & $72.54 \mathrm{a} \mathrm{B}$ & 73.8 & & $76.10 \mathrm{a} A$ \\
\hline \multirow[t]{2}{*}{ LAI } & & With & $3.12 \mathrm{a} A B$ & 3.4 & & $2.84 \mathrm{a} \mathrm{B}$ \\
\hline & & Without & $2.47 \mathrm{~b} \mathrm{~B}$ & 3.2 & & $3.00 \mathrm{a} \mathrm{A}$ \\
\hline
\end{tabular}

Means followed by the same lower case letter in the column and upper case in the line do not differ by Tukey test at $5 \%$.

Rev. Ceres, Viçosa, v. 62, n.6, p. 577-582, nov-dez, 2015 

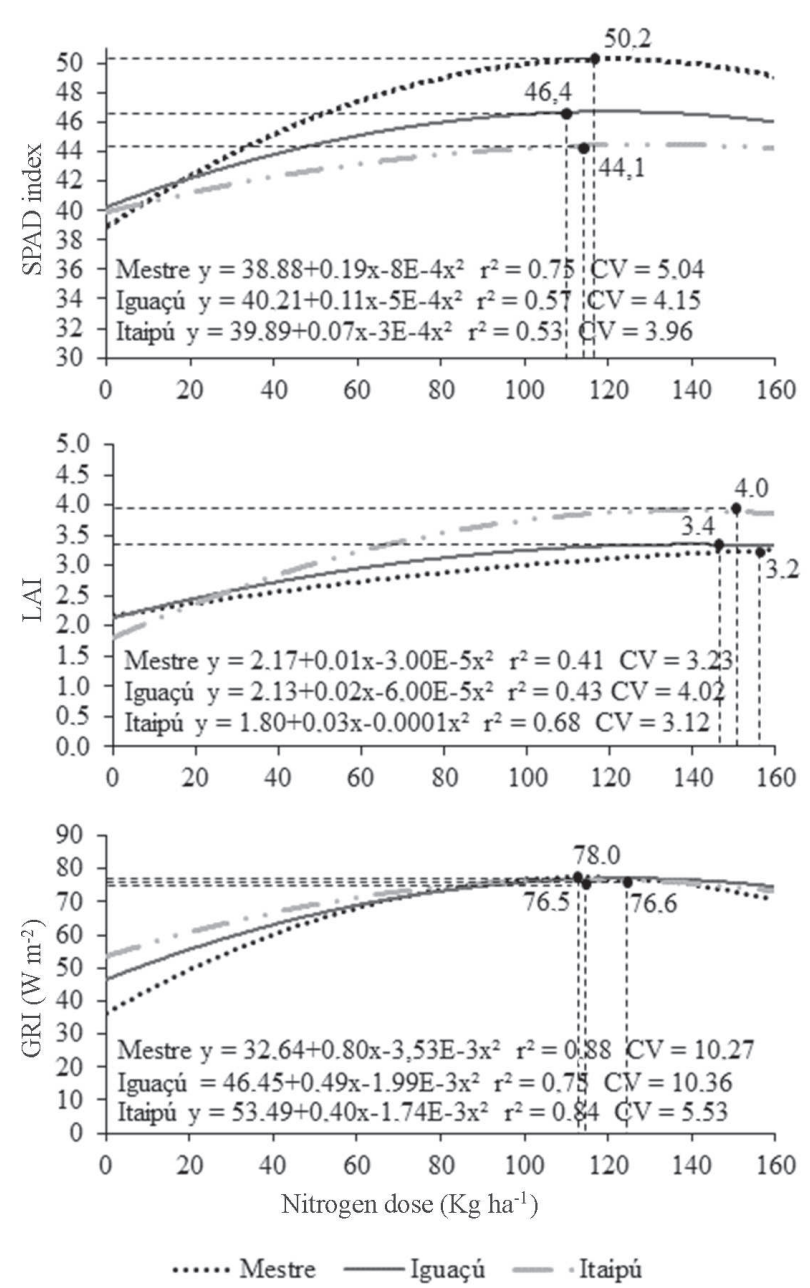

Figure 1: Regression equations for SPAD index, leaf area index (LAI) and global radiation interception (GRI) of wheat cultivars in function of nitrogen doses, regardless of the application or not of growth reducer.

In the same context, Souza et al. (2013), analyzing defoliation at different growth stages on agronomic characteristics, in wheat, found that the loss of the two upper leaves closest to the ear, in the wheat plant (flag leaf and one below), represents a decrease of $19,26 \%$ of grain procuctivity.

Knowing that the use of growth reducer provides improvement of wheat leaf architecture, the result of this work can be enhanced by the analysis of Stewart et al. (2003), who found that the way the PAR is intercepted by plant canopy is reflected in the photosynthetic efficiency and the development of the crop. Therefore, factors such as form, density and spacing, affect the distribution of leaf area in the canopy of plants and the amount of energy of incident solar radiation.

The highest leaf area index may have caused increase of the diffuse radiation fraction, incident on the leaves of the middle and lower thirds of the plant canopy, promoting greater efficiency in the use of
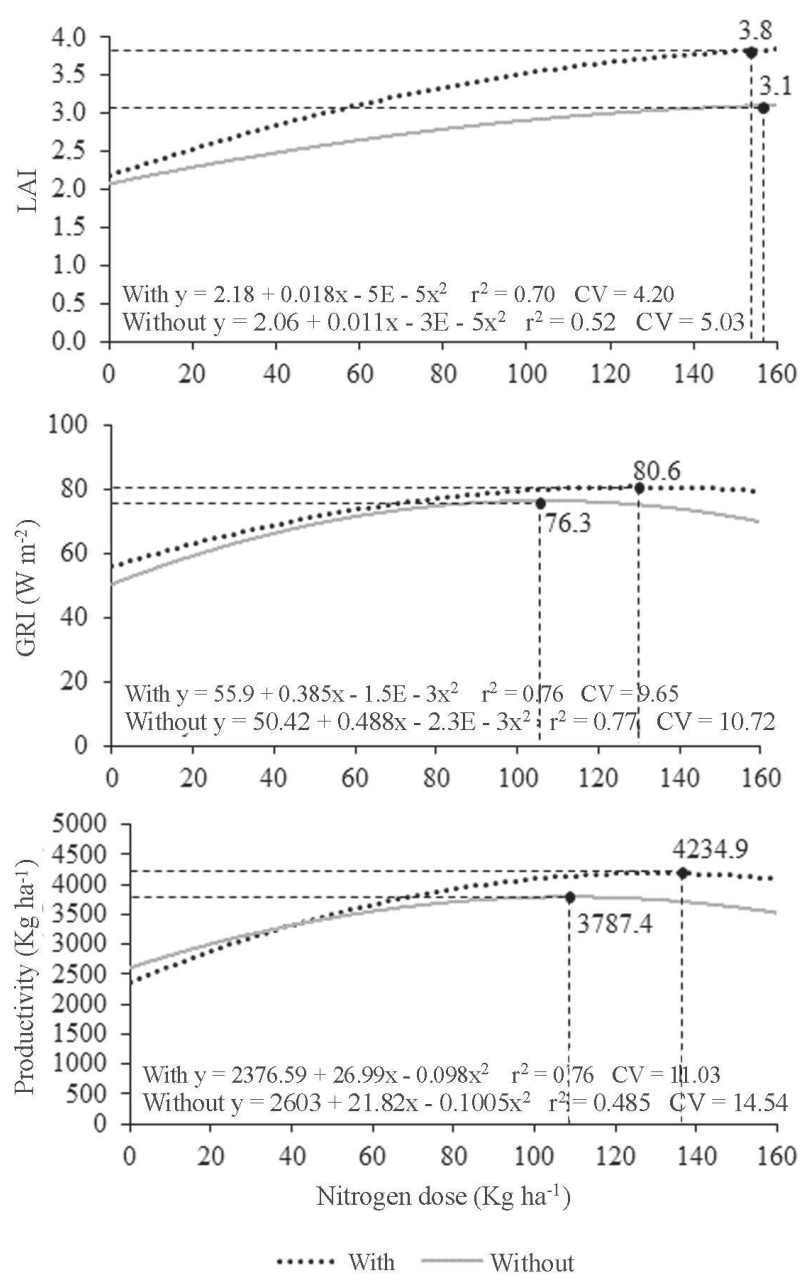

Figure 2: Regression equations for leaf area index (LAI), global radiation interception (GRI) and productivity of wheat, with or without application of growth reducer, in relation to nitrogen doses.

solar radiation. This result can be supplemented by Caron et al. (2013), who found this behavior in the yerba mate associated with Pinus elliottii, and also by Sinclair et al. (1992), who observed, for corn and soybean, that the increased diffuse radiation fraction resulted in more efficient use of radiation by the crops. This behavior may have been responsible for the significant difference among treatments with and without the application of the growth reducer, from dose of $120 \mathrm{~kg} \mathrm{ha}^{-1}$ of $\mathrm{N}$.

\section{CONCLUSIONS}

Increasing nitrogen doses promotes increased plant LAI, in wheat culture, differently among cultivars, resulting in greater global radiation interception.

In nitrogen doses greater than $120 \mathrm{~kg} \mathrm{ha}^{-1}$, there are significant differences in wheat productivity, between treatments with and without the application of growth reducer. 
The significant interaction between growth reducer and nitrogen dose showed that the use of the reducer increases the GRI at doses above and below $80 \mathrm{~kg} \mathrm{ha}^{-1}$ of nitrogen.

The nitrogen doses of 138 and $109 \mathrm{~kg} \mathrm{ha}^{-1}$ are responsible for the maximum productivity of wheat crop, being 4235 and $3787 \mathrm{~kg} \mathrm{ha}^{-1}$ with and without the use of growth reducer, respectively.

\section{REFERENCES}

Alambert MR (2010) Estimação estocástica de parâmetros produtivos da soja: uso do modelo PPDSO em um estudo de caso em Piracicaba/ SP. Dissertação de mestrado. Fundação Getúlio Vargas, São Paulo. $108 \mathrm{p}$.

Buzetti S, Bazanini GC, Freitas JG, Andreotti M, Arf O, Sá ME \& Meira FA (2006) Resposta de cultivares de arroz a doses de nitrogênio e do regulador de crescimento cloreto de clormequat. Pesquisa Agropecuária Brasileira, 41:1731-1737.

Caron BO, Lamego FP, Souza VQ, Costa EC, Eloy E, Behling A \& Trevisan R (2012) Interceptação de radiação luminosa pelo dossel de espécies florestais e sua relação com o manejo de plantas daninhas. Ciência Rural, 42:75-82.

Caron BO, Schmidt D, Manfron PA, Behling A, Eloy E \& Busanello C (2013) Eficiência do uso da radiação solar por plantas Ilex paraguariensis A. ST. HIL. cultivadas sob sombreamento e a pleno sol. Ciência Florestal, 24:257-265.

SBCS - Sociedade Brasileira de Ciência do Solo (2004) Manual de adubação e calagem para os estados do Rio Grande do Sul e Santa Catarina. Porto Alegre, Sociedade Brasileira de Ciência do Solo Núcleo Regional Sul. 400p.

Elli EF, Caron BO, Rockenbach AP, Schmidt D \& Eloy E (2013) Influência de diferentes estádios fenológicos e arranjos espaciais na interceptação de radiação global em cultivares de Glycine max L. Merril. Enciclopédia Biosfera, 9:1288-1297.

Embrapa - Empresa Brasileira de Pesquisa Agropecuária (2006) Sistema Brasileiro de Classificação de Solos. $2^{\mathrm{a}}$ ed. Rio de Janeiro, EmbrapaSPI. 412p.

Large EC (1954) Growth stages in cereals illustration of the Feeks scales. Plant Pathology, 4:22-24.

Loomis RS \& Williams W (1963) Maximum crop produtivity: a estimate. Crop Science, 3:67-72.

Lozano CM \& Leaden MI (2002) Efecto de reguladores de crecimiento sobre el rendimiento y altura en dos cultivares de trigo. In: Simpósio Nacional de Cereales de Siembra Otoño Invernal, Argentina. Anais, INTA. p.1-2.

Maluf JRT (2000) Nova classificação climática do Estado do Rio Grande do Sul. Revista Brasileira de Agrometeorologia, 8:141-150.

Pagliosa ES, Benin G, Biezus E, Beche E, Silva CL, Marchese JÁ \& Martin TN (2013) Trinexapac-ethyl e adubação nitrogenada na cultura do trigo. Planta Daninha, 31:623-630.

Pengelly BC, Blamey FPC \& Muchow RC (1999) Radiation interception and the accumulation of biomass and nitrogen by soybean and three tropical annual forage legumes. Field Crops Research, 63:99-112.

Rademacher W (2000) Growth retardants: Effects on gibberellin bioproduction synthesis and other metabolic pathways. Annual Review of Plant Physiology and Plant Molecular Biology, 51:501531.

SAS (2003) Getting started with the SAS Learning Edition. Cary, SAS Learning Edition. 200p.
Sinclair TR, Shiraiwa T \& Hammer L (1992) Variation in crop radiationuse efficiency with increased diffuse radiation. Crop Science, 32:12811284.

Souza VQ, Nardino M, Bonato GO, Bahry CA, Caron BO, Zimmer PD \& Schmidt D (2013) Desfolha em diferentes estádios fenológicos sobre características agronômicas em trigo. Bioscience Journal, 29:19051911.

Stewart DW, Costa C, Dwyer LM, Smith DL, Hamilton RI \& Ma BL (2003) Canopy structure, light interception and photosynthesis in maize. Agronomy Journal, 95:1465-1474.

Viana EM \& Kiehl JC (2010) Doses de nitrogênio e potássio no crescimento do trigo. Bragantia, 69:975-982.

Zagonel J \& Fernandes EC (2007) Doses e épocas de aplicação de redutor de crescimento afetando cultivares de trigo em duas doses de nitrogênio. Planta Daninha, 25:331-339.

Rev. Ceres, Viçosa, v. 62, n.6, p. 577-582, nov-dez, 2015 